\title{
Clear cell carcinoma of the lung
}

\author{
C EDWARDS, A CARLILE
}

From the Department of Histopathology, East Birmingham Hospital, Birmingham

SUMMARY Six tumours of the lung initially classified as clear cell carcinoma, were studied. Examination of further material by light and electron microscopy showed adenocarcinomatous differentiation in three cases and squamous differentiation in two. One case showed the features of a large cell anaplastic carcinoma. The clear appearance of the cytoplasm in paraffin sections was due to accumulations of glycogen that were partially removed during processing. It is concluded that clear cell carcinoma is not a single and separate entity.

Clear cell carcinoma of the lung is defined by the World Health Organisation as an anaplastic large cell tumour forming nests, clusters, and sheets of cells with large vesicular nuclei and an abundant clear or foamy cytoplasm, which may or may not contain glycogen.' No mucin is present, and this category does not include adenocarcinomas or squamous carcinoma with clear cells. The resemblance of such tumours to carcinoma of the kidney may give rise to diagnostic problems. Few studies of this variant of lung cancer have been reported, ${ }^{2-8}$ and only two were originally written in English. ${ }^{26} \mathrm{As}$ far as we are aware, the ultrastructure has been described in only one case. ${ }^{8}$ As widespread clear cell change can occur in squamous carcinoma and adenocarcinoma of the lung, the existence of clear cell carcinoma as a separate entity has been questioned. ${ }^{6}$ We investigated the light and electron microscopic features in six cases coming to surgery at this hospital. Our results indicate that clear cell carcinoma is a heterogeneous group of neoplasms, with only cytoplasmic accumulation of glycogen in common.

\section{Patients, material, and methods}

All the patients were heavy cigarette smokers. One patient (case 5) was thought at first to have a renal carcinoma with a secondary deposit in the lung, but intravenous pyelography, renal arteriography, and surgical exploration of the right kidney did not show any abnormality. Three patients (cases 1,2 , and 6) were treated by lobectomy, two (cases 3 and 4 ) by

Accepted for publication 27 March 1985 pneumonectomy, and one (case 5) by right upper and middle lobectomy. One patient (case 6) presented five months after operation with chest pain, dyspnoea, and haemoptysis. Radiologically, there was a cavitated tumour in the right upper lobe, and an inoperable tumour extending into the pleura was found at thoracotomy. She died two months later. The other patients did not suffer a recurrence, but the maximum follow up period was only 14 months. The table shows the clinical details of all six patients studied.

\section{LIGHT MICROSCOPY}

In each case the initial diagnosis of clear cell carcinoma was made on three paraffin sections stained with haematoxylin and eosin, periodic acid Schiff with and without diastase, and mucicarmine. These sections were reviewed, together with a bronchial biopsy from case 4 , and an open biopsy taken during the second operation from case 6 . Subsequently, up to six extra blocks were obtained from each resected specimen, and the sections were stained again with haematoxylin and eosin, periodic acid Schiff, and mucicarmine.

\section{ELECTRON MICROSCOPY}

With the exception of case 5, tissue for electron microscopy was obtained at the time of thoracotomy and fixed in buffered glutaraldehyde. In case 5 material was obtained from the specimen fixed with formalin. In all cases the tissue was fixed afterwards in osmic acid and embedded in resin tagged with typhoid-paratyphoid $A$ and $B$ vaccine (TAAB Laboratories Ltd, Reading, England). Ultra thin sections were stained with uranyl acetate and lead citrate. Between six and 10 blocks were examined in each case. 
Presenting features in patients, bronchoscopic findings, and site and size of tumour

\begin{tabular}{|c|c|c|c|c|}
\hline Case No & Age/sex & Presenting features & Bronchoscopy & Site and size \\
\hline 1 & $53 / \mathrm{M}$ & $\begin{array}{l}\text { Cough, ankle oedema, } \\
\text { finger clubbing }\end{array}$ & Normal & Right upper lobe, $6 \mathrm{~cm}$ \\
\hline 2 & $53 / \mathbf{M}$ & Asymptomatic & Normal & Left upper lobe, $5 \mathrm{~cm}$ \\
\hline 3 & $61 / \mathrm{M}$ & Asymptomatic & $\begin{array}{l}\text { Tumour of apical bronchus } \\
\text { left lower lobe }\end{array}$ & Left lower lobe, $6 \mathrm{~cm}$ \\
\hline 4 & $67 / \mathrm{M}$ & $\begin{array}{l}\text { Chronic obstructive airways } \\
\text { disease, otherwise } \\
\text { asymptomatic }\end{array}$ & $\begin{array}{l}\text { Tumour of main left lower } \\
\text { lobe bronchus }\end{array}$ & Left lower lobe, $8 \mathrm{~cm}$ \\
\hline 5 & $49 / \mathrm{F}$ & $\begin{array}{l}\text { Right upper abdominal pain. } \\
\text { palpable right kidney }\end{array}$ & Normal & Right upper lobe, $6 \mathrm{~cm}$ \\
\hline 6 & $68 / F$ & $\begin{array}{l}\text { Chronic obstructive airways } \\
\text { disease otherwise asymptomatic }\end{array}$ & Normal & Left upper lobe, $5.5 \mathrm{~cm}$ \\
\hline
\end{tabular}

\section{Results}

\section{LIGHT MIC ROSCOPY}

In cases $1,2,3$, and 5 the tumour consisted of sheets and clusters of polygonal cells up to $40 \mu \mathrm{m}$ in maximum diameter (Fig. 1). Cell borders were distinct, and the cytoplasm was water clear or foamy and faintly eosinophilic. Nuclei were 10-20 $\mu \mathrm{m}$ across and round or slightly irregular with an open chromatin pattern and often a single large eosinophilic nucleolus. There were moderate numbers of mitoses. In many fields the stroma was scanty and infiltrated by plasma cells and lymphocytes. Elsewhere it was more prominent, and some areas were scirrhous, with small aggregates of cells surrounded by cellular fibrous tissue.

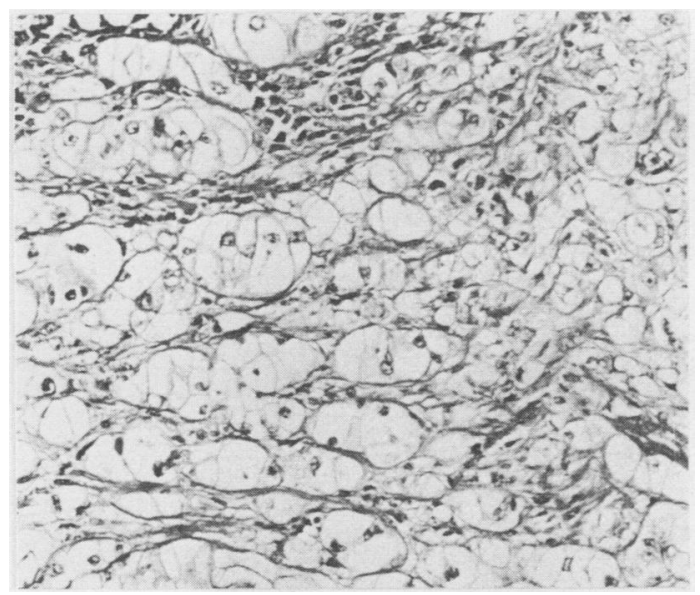

Fig. 1 Case 2. Tumour consisting of sheets and cords of large clear cells. Haematoxylin and eosin. $\times 100$.

Necrosis was variable and most pronounced in case 1 . In case 3 the periphery of the tumour showed a lepidic type of spread with preservation of alveolar walls. Hilar nodes were affected in case 2 . Abundant intracytoplasmic material, positive for periodic acid Schiff, removable by diastase, was present (Fig. 2). Stains for mucin in the original sections were negative, but in the additional material from cases 2 and 3 occasional foci of extra and intracellular mucus secretion were seen.

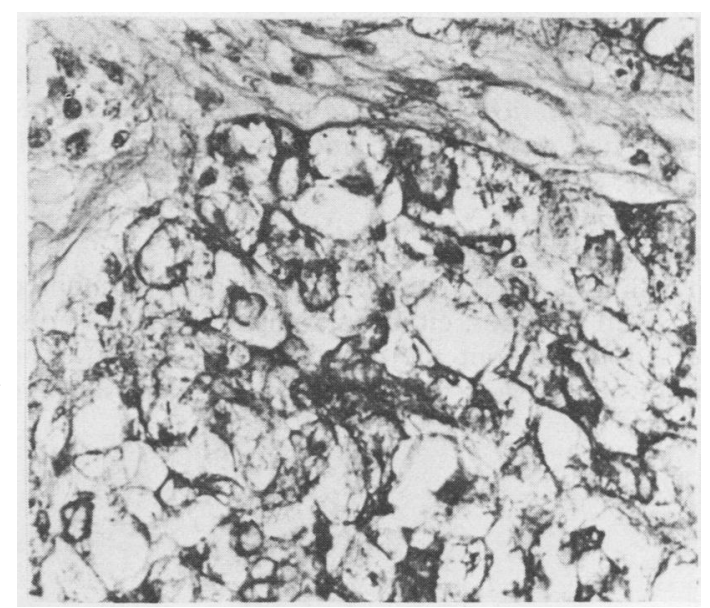

Fig. 2 Case 2. Abundant periodic acid Schiff positive matter in cytoplasm of tumour cells. $\times 252$.

In cases 4 and 6 tumour cells were arranged in broad irregular trabeculae, with pseudoacinar spaces containing cellular debris (Fig. 3). The pattern resembled that of well differentiated squamous carcinoma, but there was no stratification or keratinisation and no intracellular bridges. The cells were smaller than those in the first group, measuring up to $15 \mu \mathrm{m}$ in maximum diameter. Nuclei were oval, round, or irregular and up to $9 \mu \mathrm{m}$ across with two or three small nucleoli. Mitoses were less common. Diastase labile material positive for periodic acid Schiff was present in the cytoplasm. Stains for mucin were negative. In the extra sections from case 6 areas of unequivocal squamous differentiation were seen. Hilar nodes were not affected.

The bronchial biopsy from case 4 consisted of 


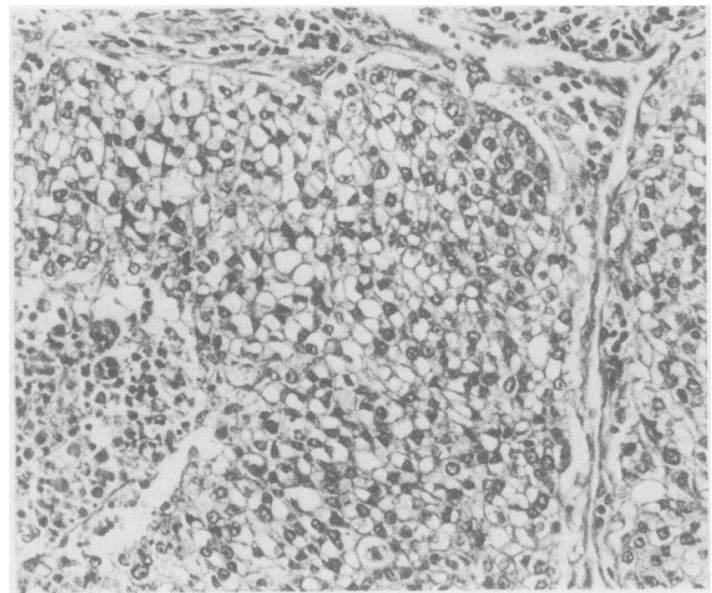

Fig. 3 Case 4. In contrast to case 2 cells are smaller and arranged in trabeculae with pseudoacini containing cell debris. Haematoxylin and eosin. $\times 100$.

normal bronchial mucosa. A specimen taken at the second operation from case 6 showed poorly differentiated squamous carcinoma without clear cell change.

\section{ELECTRON MICROSCOPY}

In all the cases most tumour cells contained glycogen granules, either in compact masses or dispersed throughout the cytoplasm (Figs. 4-7). The larger masses were sharply defined, but no limiting

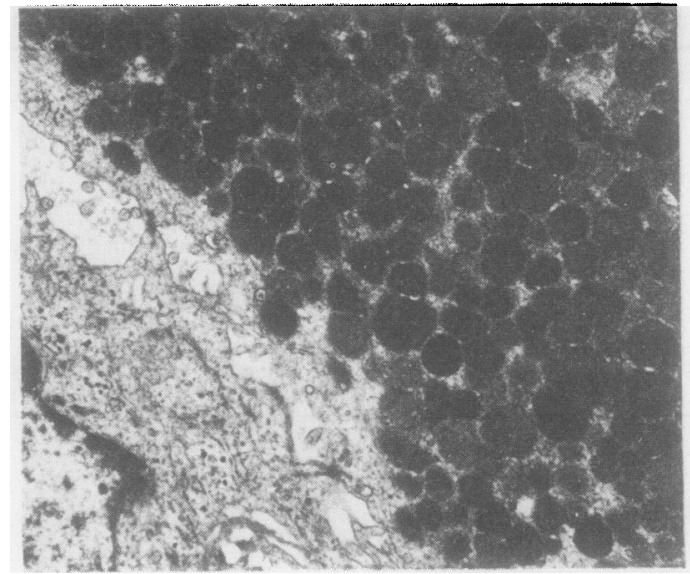

Fig. 5 Case 3. Tumour cell cytoplasm containing granules of mucus. (Uranyl acetate and lead citrate.) × 10400 .

membrane was present. In cases 2,3 , and 5 foci of adenocarcinomatous differentiation were present, with intercellular lumens lined by microvilli and bounded by tight junctions or complete junctional complexes (Fig. 4). Some cells contained numerous mucus granules (Fig. 5), whereas in others they were sparse or absent. Mitochondria were plentiful. Cisterns of smooth endoplasmic reticulum were often abundant and were sometimes dilated to form large vacuoles, which were either empty or contained a few granules of glycogen (Fig. 4). Nuclei were

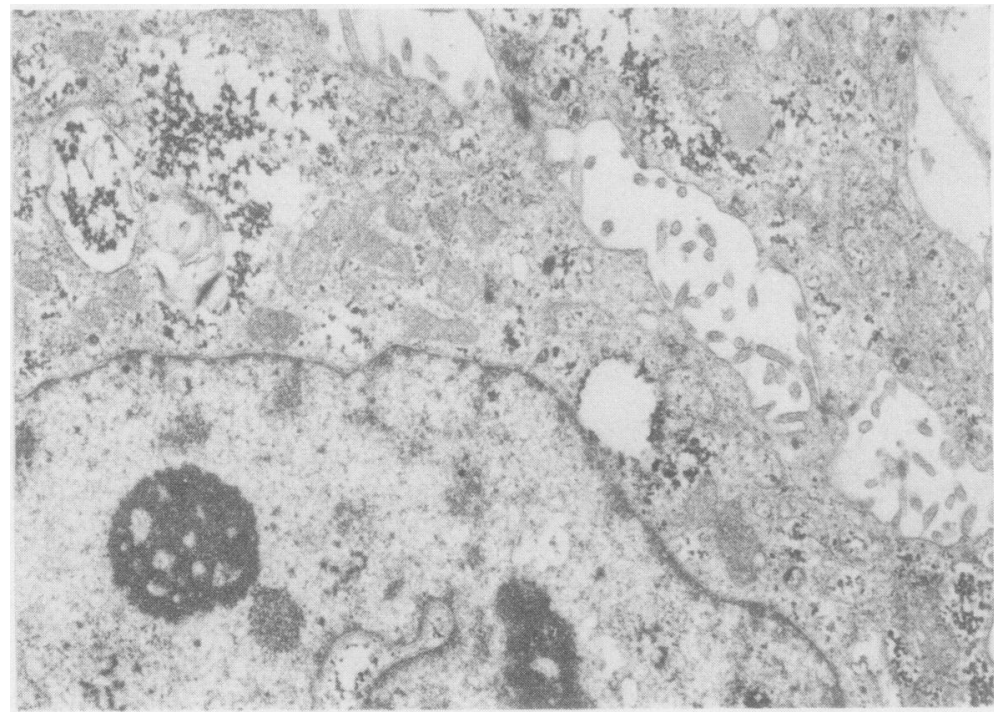

Fig. 4 Case 2. Tumour cell with surface microvilli, large irregular nucleus, and moderate amount of glycogen in cytoplasm. Dilated cysterns of endoplasmic reticulum are present and some contain granules of glycogen. (Uranyl acetate and lead citrate.) $\times 11100$. 


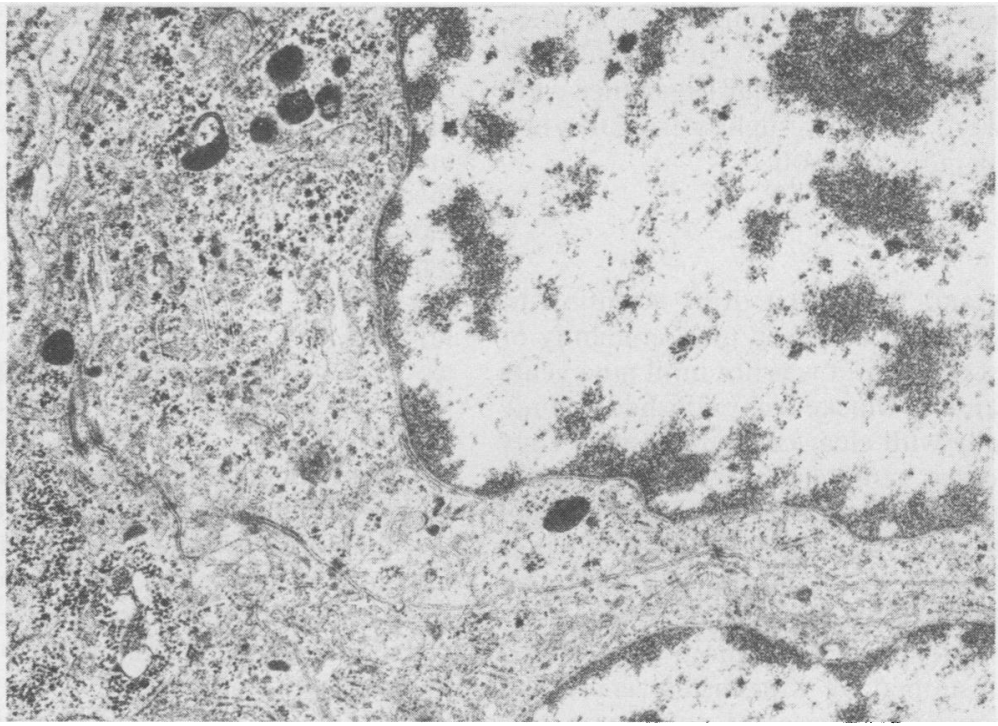

Fig. 6 Case 1. Undifferentiated cells with moderate amounts of glycogen and occasional lysosomes in cytoplasm. (Uranyl acetate and lead citrate.) $\times 12600$.

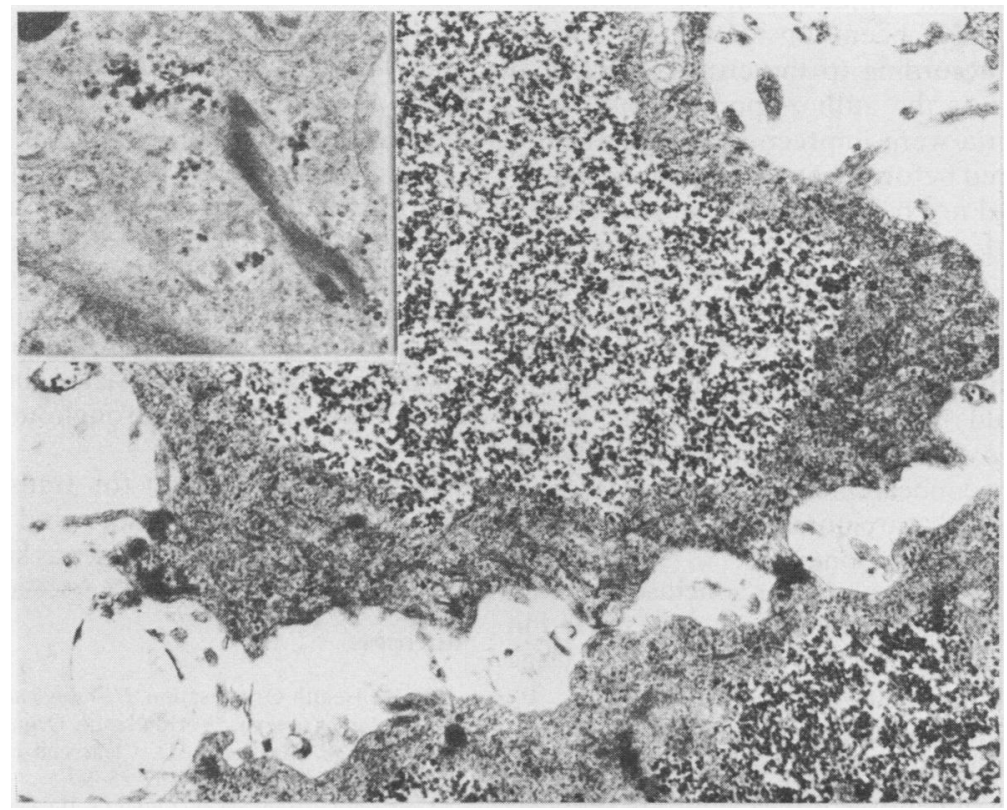

Fig. 7 Case 6. Tumour cell with a large cytoplasmic accumulation of glycogen, pseudopodal processes, desmosomes, and tonofilaments (inset, top left). (Uranyl acetate and lead citrate.) $\times 14400$ and 24000 .

irregular with prominent nucleoli. There were also areas of undifferentiated, polygonal cells with smooth cytoplasmic membranes bearing occasional tight or gap junctions (Fig. 6). Organelles were sparse, and nuclei were oval or irregular, with prom- inent nucleoli. The tumour from case 1 consisted entirely of this type of cell.

In cases 4 and 6 the light microscopic impression of squamous carcinoma was confirmed (Fig. 7). Projecting cell processes were joined by well developed 
desmosomes, and tonofilament bundles were present in the cytoplasm (Fig. 7). No granules of keratohyaline were seen, and other organelles were scanty. Nuclei were round or slightly irregular and contained one or more nucleoli.

\section{Discussion}

In 1955 Walter and Pryce first drew attention to carcinomas of the lung composed predominantly or entirely of clear cells, ${ }^{\varphi}$ but it was not until nine years later that Morgan and Mackenzie published a study dealing specifically with clear cell carcinoma. ${ }^{2}$ They described 13 cases, emphasising the peripheral origin and the resemblance to secondary renal carcinoma. Between 1966 and 1981, 27 further examples were reported, ${ }^{4-7}$ and in 1984 Smirnova et al reported the ultrastructure of one case. ${ }^{8}$

In 1980 the existence of this tumour as a distinct subtype was questioned by Katzenstein et al, who reviewed 348 consecutive cases of pulmonary carcinoma and found 15 that contained over $50 \%$ clear cells. ${ }^{6}$ These tumours, which were otherwise large cell undifferentiated, epidermoid, or adenocarcinomas, would have been considered to be clear cell carcinomas according to the criteria published up to that date. As the authors pointed out, however, these criteria were imprecise. The number of clear cells required before clear cell carcinoma could be diagnosed had not been specified, nor was there any mention of tumours showing glandular or squamous differentiation. It was concluded that clear cell change is common in all types of carcinoma of the lung except small cell carcinoma, and that even those tumours consisting predominantly of clear cells should be classified under one of the major categories, laid down by the World Health Organisation (adenocarcinoma, squamous carcinoma, or large cell carcinoma), at the same time noting the clear cell component.

Wagner's group reached similar conclusions, ${ }^{7}$ and, interestingly, clear cell change has been reported in carcinomas arising from Clara cells ${ }^{810}$ and in large cell undifferentiated carcinomas." Moreover, by modern criteria many of the earlier reported cases are not true clear cell carcinomas.' For instance, intracytoplasmic mucin was found in all the tumours collected by Morgan and Mackenzie, and over half showed acinar differentiation. ${ }^{2}$ Such tumours would now be classified as adenocarcinomas with clear cell change, as would the tumours reported by Drut et al. ${ }^{4}$

This study confirms that clear cell carcinoma is not a separate entity. Examination of further material by light microscopy alone showed mucus secretion in two cases and squamous differentiation in one.
Although three cases fulfilled the current light microscopic criteria for clear cell carcinoma, at an ultrastructural level one was an adenocarcinoma, one a squamous carcinoma, and one a large cell undifferentiated carcinoma. The clear appearance of the tumour cells is due to accumulations of glycogen, most of which is dissolved during the preparation of paraffin sections: in tissue processed for electron microscopy it is retained. This change seems unlikely to be degenerative as it is not necessarily associated with necrosis and is also seen in secondary deposits, but it may reflect an abnormality in glycolysis.

Primary carcinomas of the lung with clear cell change, secondary renal adenocarcinomas, and clear cell adenoma of lung (sugar tumour) show similar histological structure, and all contain cytoplasmic glycogen. The distinction between these tumours, which is obviously important in relation to their management and prognosis, may be impossible in small biopsies. Where the availability of tissue permits, multiple sections should be examined for evidence of mucus secretion and squamous differentiation. Renal adenocarcinomas contain neutral lipid and phospholipid, and mucopolysaccharides are not found in the cytoplasm, although they may be found in cell membranes. ${ }^{12}$ Electron microscopy shows prominent microvilli, pinocytic vesicles, vacuoles containing lipid, and often elongated and tortuous mitochondria. Clear cell adenoma shows little nuclear pleomorphism, mitoses are scanty or absent, and the cells are arranged around thin walled branching vascular channels. ${ }^{1314}$ In contrast to other clear cell tumours, the glycogen is usually contained in membrane bound vesicles, but in one reported case it was dispersed throughout the cytoplasm..$^{1314}$

We thank Dr Pandov for translating the Russian articles cited in this paper and Mrs Ruth Fry for secretarial help. This study was supported by a grant from the West Midlands Regional Health Authority.

\section{References}

' World Health Organisation. Histological typing of lung tumours. 2nd ed. Geneva: World Health Organisation, 1981.

${ }^{2}$ Morgan A, Mackenzie D. Clear cell carcinoma of the lung. $J$ Pathol Bacteriol 1964;87:25-9.

${ }^{3}$ Coppola G, Bancale A, Oliva G. Il carcinoma "a cellule chiare" del pulmone. Annali Dell' Istituto Carlo Forlanini 1965;25: 280-97.

4 Drut R, Attadema CA, Giménez PO, Chiappe L. Carcinomas de pulmón con celulas claras. Archivos-Fundacion Roux Ocefa 1970; 4:79-86.

${ }^{5}$ Hackl H. Über die clear-cell Tumoren mit besonderer berücksichtigung der Lunge. Z Erkr Atmumgsorgane 1975; 143: 110-8.

- Katzenstein AL, Prioleau PG, Askin FB. The histologic spectrum and significance of clear change in lung carcinoma. Cancer 1980;45:943-7. 
' Wagner RI, Blinov NN, Kolosov AE. Clear-cell lung cancer. Vopr Onkol 1981;27:34-9.

' Smirnova EA, Pashkova VS, Potapov YN. Clear-cell pulmonary carcinoma. Arkh Patol 1984;46:74-7.

"Walter JB. Pryce DM. The histology of lung cancer. Thorax 1955; 10: 107-16.

${ }^{10}$ Sidhu GS, Forrester EM. Glycogen-rich clara cell-type bronchioloalveolar carcinoma: light and electron microscopic study. Cancer 1977;40:2209-15.

" Churg A. The fine structure of large cell undifferentiated carcinoma of the lung. Evidence for its relation to squamous cell carcinomas and adenocarcinomas. Hum Pathol 1978;9:14356.

${ }^{12}$ Bennington JL, Beckwith JB. Tumours of the kidney, renal pel- vis and ureter. Atlas of tumour pathology. Fascicle 12. Washington: Armed Forces Institute of Pathology, 1975.

${ }^{13}$ Hoch WS, Patchefsky AS, Takeda M, Gordon G. Benign clear cell tumour of the lung. An ultastructural study. Cancer 1974; 33: 1328-36.

14 Zolliker A, Jacques J, Goldstein AS. Benign clear cell tumour of the lung. Arch Pathol Lab Med 1979; 103:526-30.

Requests for reprints to: Dr CW Edwards, Department of Histopathology, East Birmingham Hospital, Birmingham B9 5ST.

\section{The July 1985 issue}

\section{THE JULY 1985 ISSUE CONTAINS THE FOLLOWING PAPERS}

Infections in British clinical laboratories 1982-83 NR GRIST, JAN EMSLIE

Chlamydial endometritis J PAAVONEN, R AINE, $K$ TEISALA, P HEINONEN, R PUNNONEN, M LEHTINEN, A MIETTINEN, P GRÖNROOS

Detection of IgM antibodies against Chlamydia trachomatis by enzyme linked fluorescence immunoassay K NUMAZAKI, S CHIBA, T YAMANAKA, T MOROBOSHI, K AOKI, T NAKAO

Enzyme immunoassay for the detection of Chlamydia trachomatis antigen in urethral and endocervical swabs GILANFAR MUMTAZ, BJ MELLARS, GL RIDGWAY, JD ORIEL

Changes in circulating immune complex concentrations and antibody titres during treatment in $\mathrm{Q}$ fever endocarditis PV COYLE, J THOMPSON, AAJ ADGEY, DA RUTTER, A FAY, TA MCNEILL, JH CONNOLLY

Phagocytosis and killing of Gardnerella vaginalis by human neutrophils CSF EASMON, L CLARK, JP CRANE, R GREEN

Distribution of biotypes of Haemophilus infuenzae and $H$ parainfuenzae in patients with cystic fibrosis KC WATSON, EJC KERR, CA HINKS

Histopathological classification and malignant change in gastric polyps T NAKAMURA, G-I NAKANO

Quantitative assessment of the mucosal architecture of jejunal biopsy specimens: a comparison between linear measurement, stereology, and computer aided microscopy GR CORAZZA, M FRAZZONI, MF DIXON, G GASBARRINI

Density of mucosal mast cells in the lamina propria of the colon and terminal ileum of children IR SANDERSON, G SLAVIN, JA WALKER-SMITH

A quantitative study of immunoglobulin containing cells in the differential diagnosis of acute colitis JP VAN SPREEUWEL, J LINDEMAN, CJLM MEIJER
Histological features of sclerosing cholangitis in patients with chronic ulcerative colitis C BARBATIS, $P$ GRASES, HA SHEPHERD, RW CHAPMAN, JOAN TROWELL, DPJ JEWELL, JO' D MCGEE

An immunohistochemical study of branchial cysts J CROCKER, RACHEL JENKINS

Factors influencing the survival of patients with testicular teratoma JOAN M ALDERDICE, JD MERRETT

Isolated arteritis of the epididymis C WOMACK, ID ANSELL

Immunomorphological characterisation of antinuclear antibodies in chronic liver disease FCASSANI, FB BIANCHI, M LENZI, U VOLTA, E PISI

Demonstration of serum monoclonal immunoglobulin in a case of non-secretory myeloma by immunoisoelectric focusing $T$ SHEEHAN, D SINCLAIR, P TANSEY, JR O' DONNELL

Thalassaemia trait and pregnancy JM WHITE, $R$ RICHARDS, M BYRNE, T BUCHANAN, YS WHITE, G JELENSKI

Pleural fluid ferritin concentrations in human disease $M$ KLOCKARS, $T$ WEBER, $P$ TANNER, P-E HELLSTRÖM, T PETTERSSON

Platelet release protein which inhibits plasminogen activators NUALA A BOOTH, JUDITH A ANDERSON, B BENNETT

Extramedullary transformation of chronic myeloid leukaemia with a unique chromosome pattern NG FLANAGAN, CJ HARRISON, DS HARRY, JC RIDWAY

Technical method

Simplified procedure for tissue culture in routine detection of cytotoxins AR WELCH, SP BORRIELLO, FIONA E BARCLAY

\section{Letters to the Editor}

Book reviews

Notices 